\title{
Elliptical constructions of advertisements displayed on National Geographic Magazine
}

\author{
Satyawan Anshary ${ }^{{ }^{*}}$, Riski Lestiono ${ }^{2}$ \\ Pendidikan Bahasa Inggris, Fakultas Keguruan dan Ilmu Pendidikan, Universitas Muhammadiyah Malang, Malang, Indonesia \\ satyawana@gmail.com, * *iskilestiono@umm.ac.id \\ ${ }^{*}$ Corresponding author: riskilestiono@umm.ac.id
}

\begin{abstract}
Article History Received: April 2, $2020 \quad$ Revision: April 20, 2020 Available Online: April 29, 2020
ABSTRACT
Proper use of grammar is paramount as it affects the communication process between the addresser and the addressee. Ellipsis
is one of the sub-topics in linguistics that focuses on the effective use of language in any type of discourse. To put it simply,
ellipsis refers to the process of omitting/ellipting word(s) in any textual unit when the context is already established and can
be assumed. This research is aimed at investigating: (I) the types of elliptical constructions found in advertisements of National
Geographic Magazine and (2) the formulations of elliptical constructions in advertisements of National Geographic Magazine.
A qualitative content analysis design was employed, taking all the advertisements found throughout the three issues of National
Geographic Magazine from January to March 20I8 as the research objects. All of the data were examined through the following
steps: expert validation, identification, classification, and the elliptical operation analysis utilizing the concept of
presupposition. The current study has revealed that all the three types of incohesive ellipsis were employed in the printed
advertisements selected as the source material of this study. These three incohesive ellipsis types were: structural, situational,
and textual, which are respectively 2I, I8, and 6 data in total. These findings were associated heavily on the type of discourse
used, the block-style language of printed advertisement is meant to be catchy, short, and effective for the readers upon delivering
its information. This current study has come to its conclusion that ellipsis has colored the sentence formulations of
advertisement in which economy contributes to its distinct features compared to other existing discourses.
Keywords Advertisement, ellipsis, National Geographic Magazine

\section{ABSTRAK}

Penguasaan tata bahasa menjadi kunci dalam komunikasi dua arah terlebih dalam penggunaan bahasa asing. Ellipsis adalah sub-topik dalam ilmu linguistik yang mempelajari cara berkomunikasi secara efektif. Ellipsis memungkinkan peleburan dan peluruhan kata dalam unit ujaran jika konteks kebahasaan telah tercapai. Penelitian ini bertujuan untuk menginvestigasi: (I) jenis konstruksi ellipsis pada iklan Majalah National Geographic dan (2) formulasi konstruksi ellipsis pada iklan Majalah National Geographic. Pendekatan kualitatif konten analisis digunakan dalam penelitian ini, dengan mengumpulkan iklan yang terdapat pada tiga edisi Majalah National Geographic bulan Januari sampai Maret 2018. Semua data diteliti dengan serangkaian tahapan: validasi ahli, identifikasi, klasifikasi data, serta analisis operasi ellipsis menggunakan konsep presuposisi. Temuan penelitian ini adalah ketiga jenis incohesive ellipsis yang dideteksi adalah structural, situational, dan textual ellipsis berjumlah masing-masing 2I, I8, dan 6 data. Hal penentu temuan ini bergantung pada jenis teks, gaya block-style iklan yang dituntut untuk tampil menarik, ringkas, dan efektif dalam menyampaikan pesan kepada pembaca. Simpulan penelitian ini adalah sebuah gagasan bahwa ellipsis mewarnai konstruksi kalimat supaya secara ringkas dapat menyampaikan pesan yang diinginkan.
\end{abstract}

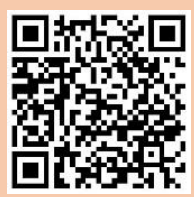

Copyright@2020, Satyawan Anshary \& Riski Lestiono This is an open access article under the CC-BY-3.0 license

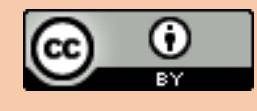

\begin{tabular}{ll} 
Kata Kunci & Iklan, Konstruksi ellipsis, Majalah National Geographic \\
\hline How to Cite & Anshary, S \& Lestiono, R. (2020). Elliptical construction of advertisements displayed on National \\
& Geographic Magazine. KEMBARA: Jurnal Keilmuan Bahasa, Sastra, dan Pengajarannya, 6(I), I04-I I4. \\
& doi: https://doi.org/I0.222I9/kembara.v6iI.II760
\end{tabular}

\section{INTRODUCTION}

Advertisement is a collection of short 'verbal' texts that are commonly accompanied with 'visuals' which makes it interesting for the audiences who interact with them (Lunyal, 20I4). This is in line with the previous concept of advertisements proposed by Cook (200I) who defines advertisement as a combination of 'language' and 'images'. Upon identifying advertisement, several elements that are 
common and relevant to the object of the study need to be broken down first. The source material used in this study is the advertisement in the form of printed paper magazine that comprises both visual and verbal elements. To comprehend this further, several definitions need to be brought. The concept of verbal and visual are presented in order to specify and associate the focus of the discussion, both of which are elaborated as follows.

Adapted from Krauss (2002), verbal is defined as "of or concerned with words". Both sign languages and writing are generally understood as forms of verbal communication, as both make use of words. Hence, verbal component in the context of advertisement is the written words or text. A text is an actualization of the language use. We identify a piece of language as a text as soon as we recognize that it has been produced for a communicative purpose (Widdowson, 2007). The communicative purpose is essential to a text, because in the actual use of language i.e. text, it is a means to connect the reader to the text. If a text does not communicate, its reader will not realize the meaning and intention of that text (Mikhchi, 20II).

Visual language is the intentional use of culturally acquired signs in culturally established patterns for the purpose of communication (Debes \& William, I978; Fromkin, Rodman, \& Hyams, 2018; Yule, 2016). The forms that visual language can take are three following divisions: body language (i.e., the use of gestures and bodily movements for non-verbal communication); object language (i.e., the use of objects for non-verbal communication); and sign and symbol language (i.e., the use of sign and symbol systems, for example Isotypes and Blissymbolic, for non-verbal communication). Moreover, differentiating the verbal and visual component in printed paper ads as the focus of the analysis is a little bit tricky. This is because an advertisement could have a photo of particular product/things that contains text, designed logo or stylized font-like symbols that could not be specified into specific classification because somehow, there is no clear divining line between them.

Furthermore, in this study, the focus of the analysis will only be limited to the primary and secondary announcement of the advertisement, as these two were mostly formed in the form of phrasal unit instead of a complete sentence, thus subjected to the ellipsis study. In addition, Yuen (2004) also claims that the primary announcement is the most prominent linguistic component in a printed advertisement. On the surface, mostly the language structures of the observed advertisements are in the form of collective noun phrase arranged together which seemingly do not form a complete sentence or sentences. Appearing this way, these stretches of words are problematic; therefore, to understand how it works, these advertisements will be analyzed further.

In order to determine that the words in an advertisement are not just words but sentences, the concept of ellipsis must be obtained. According to Martin (200I), "Ellipsis (or elliptical construction) refers to resources for omitting a clause, or some parts of a clause or group, in contexts where it can be assumed". In line with this, Downing (2003) asserts that ellipsis along with presupposition may affect the establishment of a conversational tone upon advertising discourse through the relational set up between "... characters of the fictional world and addressee ...". By and large, ellipsis is the omission of particular elements of a discourse, that could be in the form of a clause or word without changing the meaning, given that the context is already established and clear as the reader could infer the information of the omitted element, the purpose is to shorten and make the sentences more effective.

There are very diverse types of ellipsis and each of their sub-types, but on the very surface, ellipsis may be divided into two different categories; those are cohesive and incohesive ellipsis: however, understanding that the categorization might be too many, this study will concentrate its investigation of ellipsis only to the types of incohesive ellipsis. As the object of this study is advertisement which could be classified as functional text, therefore the subdivision of incohesive ellipsis is considered to be the most appropriate and relevant type to investigate the problems of this study.

Incohesive Ellipsis focuses on the occurance of an elliptical construction within the sentence, between individual clauses; in which it is perceived from or presupposed based on the intra-sentence 
perspective. Moreover in the later year, Quirk and Greenbaum (1990) categorize the incohesive ellipsis to three types; textual ellipsis, structural ellipsis, and situational ellipsis:

According to Biber, Johansson, Leech, Conrad, and Finegan (I999), textual ellipsis is defined as the recoverable omitted elements from the linguistic context. Hence, it can be said that in order to interpret the textual ellipsis, it depends on what has been said or written in that specific linguistic context. Furthermore, Quirk and Greenbaum (1990) categorize textual ellipsis into anaphoric and cataphoric ellipsis. In the former, the interpretation will be dependent on what comes before. The following example may help to illustrate the said definitions:

- She was poor but (she was) honest. (Swan, 2005)

On the contrary, in the latter, the interpretation will be dependent to what comes after. According to Broughton (1990) view, cataphoric ellipsis is less common and it makes the sentence to be a bit harder to read.

- Those who prefer (to stay indoors), can stay indoors. (Quirk \& Greenbaum, 1990)

Textual ellipsis is strongly connected to the missing elements within the sentences that have at least two clauses. If a particular sentence consists of only one clause, it will not be possible to apply incohesive ellipsis. Moreover, the textual ellipsis is divided even further into different parts in accordance to which elements are being ellipted. It may be differentiated based on ellipsis of subject, auxiliary, predicate, direct object, subject complement or adverbial.

Crystal and McLachlan (2004) identifies structural ellipsis as a special type of ellipsis where the grammar comprehension is required in order to determine the full form of a sentence. For example:

- I believe (that) you are mistaken.

The other elements that could be ellipted in structural ellipsis are determiners, particles, pronouns operators and other closed-class words. Furthermore, Quirk and Greenbaum (I990) claim that structural ellipsis commonly occurs in block-language, like headlines, book titles, and other variety of similar writings. Based on its occurrence, it can be said that the structural ellipsis takes form as a device of economy where components of little informational value are omitted as depicted in the following example.

- (The) US (is) heading for (a) new slump. (Quirk \& Greenbaum, 1990)

Situational ellipsis refers to a kind of omission commonly used in informal speech. Swan (2005) postulates that if the meaning is already clear, the unstressed words are mostly ellipted at the start of a sentence. Similarly, Biber et al. (1999) define the situational ellipsis as the case of leaving out words with contextually low information value, at the beginning of a turn, a clause, or (occasionally) a non-clausal unit. The following example is the instance of elision:

- (Have you) seen Lucy? (Swan, 2005)

The purpose of elision or situational ellipsis is in consonance to the general purpose of ellipsis as a whole, that is to economize the speech, as it has described by Tárnyiková (1992). Broughton (I990) observes that the utilization of expressions with elision appears to be more frequent in contrast to their non-ellipted forms such as:

- (I) thank you.

In accordance with all previous definitions, the source text utilized in this study is National Geographic Magazine, as it comprises various types of advertisements and is widely known at international level. Hence the language used in the advertisements is English and considered to be the most proper and relevant field for this study. National Geographic itself is the official media sources in the form of magazine founded by the National Geographic Society, one of the most powerful cultural institutions in United States in I888 as a journal for scholarly audience (Nugroho, 2009; Pérez-Marín, 2016). The magazine is published monthly, discussing the specific theme and variety of topics on each of its release. The topic discussed on this platform varies widely from science, geography, history, to world culture. The magazine as a medium provides some spaces for the advertisements beside the main contents as its common format. The National Geographic is also considered to be one of the most popular magazines worldwide and has significant international circulation, resulting in many published editions 
covered in other language all around the world. Very few researches have been devoted to investigate National Geographic magazine, particularly on the issue of ellipsis in its advertisements. Accordingly, this current study sought for the quest to show its novelty and urgency compared to other previous studies (Astuti \& Imaniah, 2019; Bakti \& Laila, 2017; Rosmiyati, 2019).

Accordingly, because of its popularity and global scope of contents, the three advertisements found on the latest issues from January until March 2018, in which the time marks the initial period of this study, were taken as the subject of the analysis. This specific time frame was chosen because they displayed the most productive advertisements which mostly contain elliptical constructions. Therefore, this current study was aimed to analyze the three editions of which that are representative to be investigated. Later, the findings will be highly contributing to the linguistics realm (e.g. syntax) as well as English language component (grammar).

\section{METHOD}

This current study employed a qualitative research design, specifically named qualitative content analysis, to dig out the detailed information on the types and formulations of the elliptical constructions. In consonance to that, Ary, Jacobs, and Razavieh (2010) further suggest that document analysis suits the purpose of this study. Accordingly, document analysis was utilized for this study's qualitative design, as it matches with the data used in this current study context. The printed advertisements are identified to be having both written (text, transcripts) and non-written characteristics (photograph, pictures).

The printed advertisements found in the National geographic magazine in the specific time frame were taken as the objects of this study. There are three issues of National Geographic Magazine that are used as the source materials:

I. "Why Birds Matter" is the issue of National Geographic Magazine released on January 2018. Based on the slight observation, this edition contains $\mathrm{I} 3$ advertisements in total.

2. "The New Big Brother" is the issue of National Geographic Magazine released on February 2018. This edition comprises II advertisements.

3. "Through an Astronaut's Eyes" is the issue of National Geographic Magazine released on March 20I8. This edition covers the total of I 4 advertisements.

On the surface, there are 38 advertisements in total, but the analysis was further filtered to avoid the repeated use of same materials that were included throughout each issue, so the number decreased after the data selection process. The data were collected through some steps: downloading the online materials of the three issues of the NatGeo magazine, listing all the advertisements found throughout the three issues of the NatGeo magazine, filtering and selecting all the advertisements found to avoid repetitive data and transferring the text into transcripts to be analyzed further.

After all the data had been collected, several procedures were applied. Firstly, two phases of validation processes were applied. In the early phase, after the data have been collected, the eligibility of the data provided was proven by means of elliptical requirements introduced by Quirk, Greenbaum, Leech, and Svartvik (1989). In the later phase, after the data had been analyzed, the final findings are further validated by a linguist and grammar lecturer with the expertise in syntax with a total of I0 year experiences in the specified field. The second step was to identify all ellipsis found in all of the data and to further classify the types of ellipsis based on the reviewed theory of the Quirk and Greenbaum (1990) categorization of Ellipsis, specifically the Incohesive ellipsis types that have been referenced previously. Lastly, the elliptical constructions that had been found were further analyzed by using Halliday and Hasan (1989) concept of presupposition to understand the text formulation even clearer. Consequently, as the advertisement comprises both verbal and visual components, the latter component will be utilized to help presuppose the ellipted elements through the use of its visual component (pictures/photographs). 


\section{FINDINGS AND DISCUSSION}

After the selection process, all the 38 data were decreased into 27, sorting out the 9 exact same copies of ads throughout the three issues. However, out of all the 27 ads, only 23 of them employ the elliptical operation.

\section{Types of the Elliptical Constructions}

Based on the results of the data analysis, there were the total of 6 textual ellipsis, 2I structural ellipsis, and I8 situational ellipsis types distributed among all the 23 advertisements.

Table I

Samples on Data Classification of Ellipsis Types and its Ellipted Elements

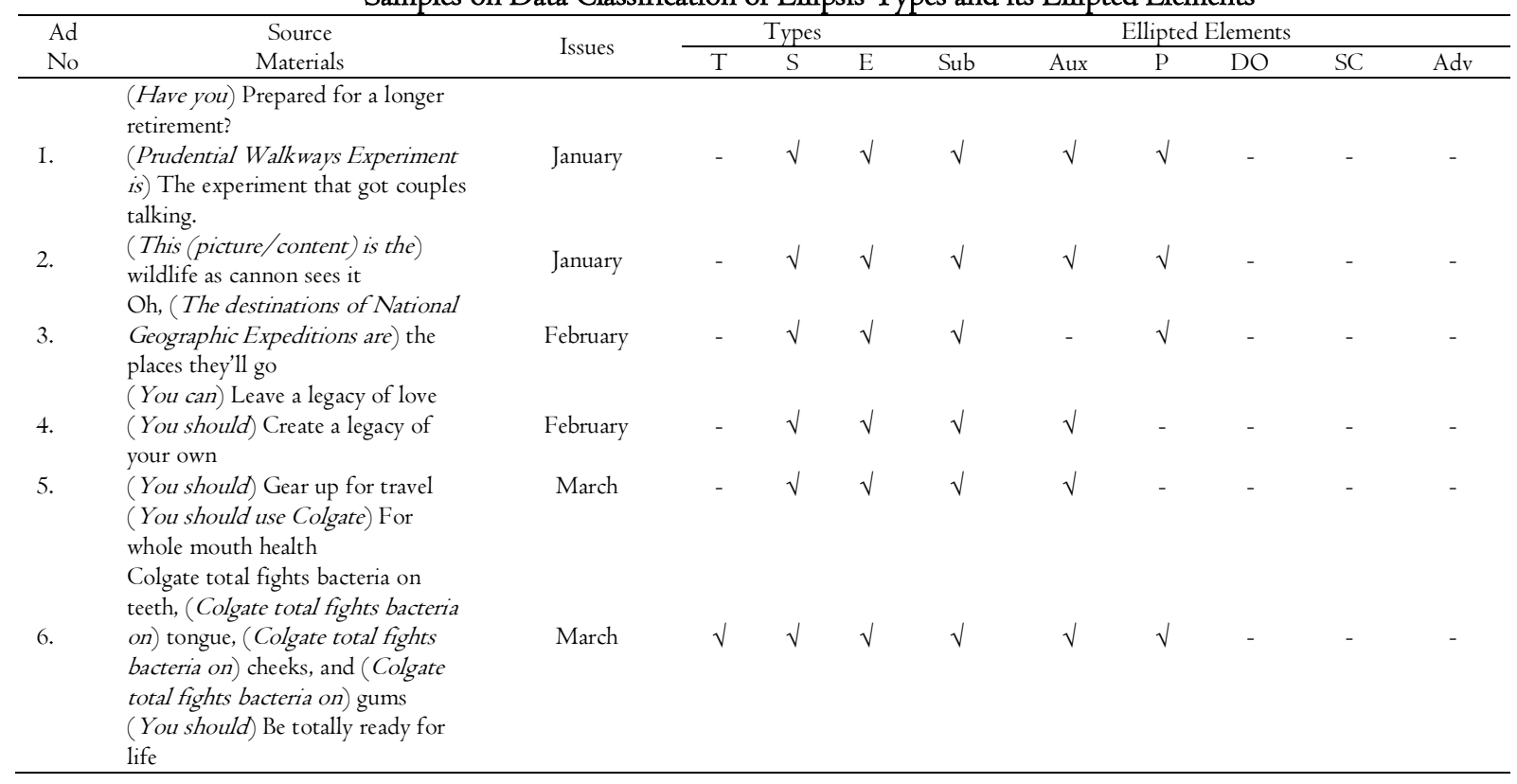

Notes:

Ellipted Elements

- Sub : Subject

- DO : Direct Object
- SC : Subject Complement
- Adv: Adverbial

Types

- Aux : Auxiliary

$-\mathrm{P} \quad$ : Predicate

- SC : Subject Complement

$-\mathrm{T}:$ Textual

$-\mathrm{S}$ : Structural

- E : Elision/Situational

\section{Textual Ellipsis type}

Based on the findings of this study, in the category of textual ellipsis, six ads are classified into this type. The data were distributed among all the three issues, 3 of which were on the January issue, I on February issue, and 2 on March issue. Notice the following examples:

\section{- The road to your happy place is paved with raisins and flakes. (ad no 4)}

The textual ellipsis has been spotted due to its basic standard of requiring two or more connected clauses. In the above examples, the textual ellipsis are identified because the sentence contains more than one clauses and has several words missing, the missing/ellipted elements can be presupposed based on the realized items in the former (anaphoric) or in the later clause (cataphoric). To understand this better, the following sentences are presented to provide better understanding of this ellipsis type:

- The road to your happy place is paved with raisins and (ellipted elements) flakes. (ad no 4) 
After these sentences are identified, further analysis needs to be done to acquire the precise ellipted elements. The analysis of the formulation will be presented in later part of this chapter.

\section{Structural Ellipsis type}

In the case of structural ellipsis of this study, 2I ads have been identified, with the total of IO ads in January issue, 4 on February issue, and 7 on March issue. Identifying a sentence as a structural ellipsis is a bit different from the textual ellipsis, as it needs to acquire the missing word(s) first. At the first glance, if the missing word seems to be the low classed words (determiner, auxiliary, preposition, conjunction, particles, etc.) then it is classified as a structural ellipsis. It has been said that structural ellipsis most commonly found in block-style type of text. The following examples are the case of structural ellipsis:

- A simple movement can make a big difference (so) Please turn off the faucet (ad no 8)

The above examples are classified as the structural ellipsis types because the words "so" is considered as the word with low informational value or as commonly known as low classed word.

\section{Situational Ellipsis type}

Lastly, the findings related to the situational type in this study have revealed the total of 18 ads, 8 on January issue, 4 on February issue, and 6 on March issue. The example of situational ellipsis type is as follow:

\section{- (ellipted elements) the quickest way to adventure (ad no I0)}

The above example is illustrating the situational ellipsis type quite obviously. The missing words are placed in the initial position of the sentence/phrase. Therefore, it is subjected to the type of situational ellipsis.

\section{Formulation Analysis of the Elliptical Constructions}

The following segment presents several examples on each type of incohesive ellipsis category and possible pattern combinations of the ellipted elements, analyzing the text, and breaking down the elliptical operation processes in order to give the clarity on how they were formulated.

\section{Textual Ellipsis Formulation}

Based on the findings of this study, in the category of textual ellipsis, there was no direct object as the ellipted element to be found, the textual ellipsis only employs the ellipted elements combination between the subject, auxiliary, predicate, and subject complement. The most common pattern would be (subject+auxiliary+predicate) or (subject+predicate) as can be seen on the Table 2 below. Additionally, there is one case that has (subject+ + predicate + subject complement) pattern. The pattern combination may not be limited to that and could be more varied, but the data is presented based only on the limited amount of source material, of 23 ads.

Table 2

Textual Ellipsis with the Ellipted Subject and Predicate

\begin{tabular}{|c|c|c|}
\hline No & Advertisement & Ellipted Element(s) \\
\hline 4 & Kellogg's Raisin Bran & $\begin{array}{l}\text { The road to your happy place is paved with raisins and (the road } \\
\text { to your happy place is paved with) flakes. } \\
\text { And (the road to your happy place is paved with) pavement. }\end{array}$ \\
\hline
\end{tabular}

The construction of the first text is a complete sentence "The road to your happy place is paved with raisins and flakes." followed by the additional phrase "And pavement." right after the use of fullstop. 
The use of fullstop (.) on each of the phrase in ad no 4 may seemingly indicate an individual text construction. It is intentionally constructed that way to establish its comedic tone by using the inefficient and repetitive word "and" twice after the fullstop, separating the word "raisins and flakes" with "pavement" as the object of the sentence. below:

In order to understand this better, the possible presupposition of the ellipted elements are presented

- "The road to your happy place is paved with raisins and (the road to your happy place is paved with) flakes."

The second phrase could also be presupposed using the same pattern as the context of information is still connected.

- "and (the road to your happy place is paved with) pavement"

In textual ellipsis, the presupposed items are more absolute in comparison to structural ellipsis as the ellipted elements are obtained based on either cataphoric or anaphoric formulation on each of its clauses. In the case of ad no 4 , the ellipted elements are the subject and predicate, as they are identical and already realized in the first clause (anaphoric formulation).

\section{Structural Ellipsis Formulation}

In the case of structural ellipsis of this study, the pattern of the ellipted elements is only limited to either ellipted auxiliary, predicate, adverb, or even the combination between the two or all the three elements. This is reasonable because the words with low informational value or as commonly known as closed-class words (determiner, auxiliary, preposition, conjunction, particles, etc.) are often found and can be roughly categorized into the mentioned three elements (auxiliary, predicate, and adverb). The following section displays the analysis in regards to structural ellipsis:

Table 3

Structural Ellipsis with the Ellipted Adverb

\begin{tabular}{ccc}
\hline No & Advertisement & Ellipted Element(s) \\
\hline Colgate Campaign & A simple movement can make a big difference \\
\#EveryDropCounts & (so) \\
& Please turn off the faucet \\
\hline
\end{tabular}

One of the purposes of the structural ellipsis is to economize the use of words in context of achieving the communicative purpose of particular block style discourse. The sentence " $A$ simple movement can make a big difference" 8 the adverbial phrase "please turn off the faucet" on the ad no 8 can be considered as structurally independent. However, in that established context, both clauses are intended to be interconnected. Hence, the use of conjunction like "so" to connect the sentence may be presupposed as the ellipted elements, since the word is considered to be having low informational value. The structural ellipsis is identified and the presupposed construction is displayed below:

- "A simple movement can make a big difference (so) please turn off the faucet"

\section{Situational Ellipsis Formulation}

Lastly, the findings related to the situational type in this study have found the common pattern combination of (subject+auxiliary) or (subject+predicate) as its ellipted elements Table 4, but also the combination between all three (subject+auxiliary+predicate) in rare cases like in ad no I5 (table I) "You should use Colgate) For whole mouth health". In comparison to the previous type, if the ellipted elements 
are either open class words (subject, direct object, etc.) or closed class words (auxiliary, adverb, etc.) but is placed in the start/initial part or the sentence/clause, then it is identified as situational ellipsis. It means that situational ellipsis could cover any word if it is possible to be presupposed. However, in this study, the direct object, adverb, and subject complement were not found due to the limited amount of data. The following section presents the analysis of situational ellipsis:

Table 4

Situational Ellipsis with the Ellipted Subject \& Predicate ( + structural ellipsis with the ellipted predicate)

$\begin{array}{ccc}\text { No } & \text { Advertisement } & \text { Ellipted Element(s) } \\ \text { I0 } & \text { Toyota RAV4 Adventure Grade } & \begin{array}{c}\text { (Toyota RAV4 Adventure Grade is) the } \\ \text { quickest way to adventure }\end{array}\end{array}$

Based on the ad no I0, on the surface, its sentence is problematic because some words have been ellipted. This sentence falls into the category of situational and structural ellipsis, as the subject together with the verb auxiliary are being the initial ellipted elements.

- "((subject) is $)$ the quickest way to adventure"

Furthermore, in order to obtain the ellipted subject, it is necessary to understand the context of the ads. The phrase is not constructed to describe the addressee of the content, so the most possible subject is the advertised product itself, the following sentence may best describe the complete form of the ellipted sentence:

- "((Toyota RAV4 Adventure Grade) is $)$ the quickest way to adventure"

In conclusion, the above analyses have successfully provided the answers to the types and the formulations of each ads that were utilized as the source data material of this study.

Departing from the data analysis, it has arrived into a conclusion that the most common types of ellipsis used in printed advertisement are situational and structural ellipsis. This is because the formulation of ellipting the initial part of the sentence is the most efficient way in the case of printed ads, as they have the visual component to support the establishment of the context of the ellipted subject, and not dependent on the cohesion nor intertextuality. Structural ellipsis is also common because the block-style language of printed advertisement is considered as the most proper medium on delivering the information as efficient as possible. Textual ellipsis, however, is rarely found due to its nature of requiring two or more interconnected clauses in the form of compound or complex sentences.

Furthermore, this study is not aimed at obtaining the absolute answers to the ellipted elements but more into how the ellipsis is formulated and what types of incohesive ellipsis that are being used. It is worth noting that in the case of structural and situational ellipsis, the result of the analyzed presupposition may not be absolute in contrast to the textual ellipsis. It can be interpreted with various equally acceptable interpretations. This is because the ellipted elements are presupposed based on the established context of the situational, structural, and grammatical comprehension of readers. It is in line with the claim made by Quirk et al. (1989), where they explained that, in situational ellipsis "the interpretation may depend on knowledge of precise extralinguistic context". However, it is stated in the theoretical review that the words ellipted in structural and situational ellipsis must only be those that possess low informationalvalue, hence the readers would have no problem in understanding the meaning of the advertised content, keeping its communicative purpose intact.

Moreover, it is easier to acquire the answer to the ellipted elements in the case of textual ellipsis since the requirement is specific merely to the anaphoric or cataphoric formulations. These two formulations follow the basic pattern that the ellipted elements are identical to the realized items that have been established within the two or more clauses. 
Therefore, the findings of this study has revealed that an ad may employ one of the types, two of the types or even all the three types of ellipsis at the same time. Even further, each type could also cover up to 3 different ellipted elements. The numbers of the pattern combinations between the types and its ellipted elements may be more than what have been shown in the data result displayed; however, the pattern combinations found in the findings were only up to 3 ellipted elements on each type.

This current study has resulted in comparably relevant findings to previous studies and underpinning theories. All the analyzed advertisements have met the criteria postulating that verbal texts in advertisement are commonly accompanied with visuals (Lunyal, 20I4). This is also in accordance with the previous notion of advertisements proposed by Cook (200I) defining advertisement as a combination of 'shortened language' and 'images'. The shortening of expressions in advertisement as a discourse has been in line with the ideas conveyed by theorist, in which it serves as a means of facilitating communicative purposes (Widdowson, 2007). Now that this current study has found out various types of ellipsis and the possibility of one advertisement belonging to more than one type, it confirms the previous studies that the use of ellipsis offers a solution to achieve communicative purpose of a text (Astuti \& Imaniah, 2019; Bakti \& Laila, 2017; Mikhchi, 20II; Rosmiyati, 2019). The aim is to hook the reader to the message of an advertisement that is to deliver the intention of introducing a certain product or of a campaign, and thus a marketing purpose as the ultimate goal.

\section{CONCLUSION}

Based on the result of data collection and analysis, it has been found that all the three types of incohesive ellipsis, i.e. textual, structural and situational, were employed in the printed advertisements selected as the source material of this study. In consonance to that, the structural type is the most common type of ellipsis that were found with the total of 2I data, followed by situational ellipsis with I8 and the least is textual ellipsis with only 6 . These findings were associated heavily on the type of discourse used, the block-style language of printed advertisement is meant to be catchy, short and effective for the readers upon delivering its information. It is intentionally made that way for delivering as many information as possible in short time span and avoiding unnecessary confusion. Hence, most of the time, the information was written in the form of collective unit of textual phrases and not a complete sentence. This is what makes the textual ellipsis to be the least type that was found due to the reason that it requires two or more clauses connected together. As for situational and structural types that are known for ellipting words with low informational value, the informal speech-like language style of an advertisement is really making them to be the best options for that effective communication.

Moreover, it has been revealed that a unit of text within the advertisement could use not only one but two or even all the three types of ellipsis at the same time. Even further, each type could also cover up to 3 different ellipted elements with various pattern combinations. In conclusion, proper grammatical understanding in any type of discourse is imperative as it affects the communication process between the addresser and the addressee. In this case, the proper use of elliptical construction has been discussed. All the sub-types of incohesive ellipsis, i.e. textual, structural and situational, were employed in multiple occasions and sometimes combined to form the effective language construction for the related ad. The implication of this study is the introduction of ellipsis concept into syntax and grammar classes. As for further researches, it is recommended that ellipsis be investigated in other text types (such as poem, jingle, song, and other functional texts) to result in more elaborated findings on how ellipsis is constructed in various formulations across discourses.

\section{ACKNOWLEDGEMENTS}

The researchers would like to send gratitude to English Language Education Department, Faculty of Teacher Training and Education, University of Muhammadiyah Malang, for incessant supports during the research conduct, data collection, data analysis, and writing completion. 


\section{REFERENCES}

Ary, D., Jacobs, L., \& Razavieh, A. (2010). Introduction to research in education 8th edition. Boston: Wadsworth Cengange Learning.

Astuti, N., \& Imaniah, I. (2019). An analysis of the tenth grade students' difficulties on elliptical constructions at MAN I Kota Tangerang Selatan. Globish: An English-Indonesian Journal for English, Education, and Culture, 8(I), I0-I7. doi: http://dx.doi.org/I0.3I000/globish.v7i2.I049

Bakti, D. P., \& Laila, M. (2017). The analysis of elliptical construction in the transporter refueled movie: Discourse approach. (Skripsi), Universitas Muhammadiyah Surakarta, Surakarta.

Biber, D., Johansson, S., Leech, G., Conrad, S., \& Finegan, E. (I999). Longman grammar of spoken and written English. Harlow: Pearson Education Ltd.

Broughton, G. (1990). The penguin English grammar $A-Z$ for advanced students. London: Penguin Books.

Cook, G. (200I). The discourse of advertising. London: Routledge.

Crystal, D., \& McLachlan, E. (2004). Rediscover grammar. Harlow: Pearson Education Ltd.

Debes, J. L., \& William, C. M. (1978). Visual literacy, language and learning: provocative paper series I. Washington DC: Gallaudet College, Visual Literacy Center.

Downing, L. H. (2003). Text world creation in advertising discourse. Círculo de lingüística aplicada a la comunicación, 5(I3), I-8. doi: https://doi.org/I0.I4I98/raei.2000.13.06

Fromkin, V., Rodman, R., \& Hyams, N. (2018). An introduction to language. Melbourne: Cengange Learning Australia Pty Limited.

Halliday, M. A. K., \& Hasan, R. (I989). Language, context, and text: Aspects of language in a socialsemiotic perspective. Oxford: Oxford University Press.

Krauss, R. M. (2002). The psychology of verbal communication. International Encyclopaedia of the Social and Behavioral Sciences. London: Elsevier, I6I6I-I6I 65.

Lunyal, V. (20I4). Examining the discourse of perfume advertisements: An analysis of the verbal and the visual. Journal of NELTA, I9(I-2), II7-I3I. doi: https://doi.org/I0.3I26/nelta.vI9iI2.I 2085

Martin, J. R. (200I). The handbook of discourse analysis. In D. Tannen, H. E. Hamilton \& D. Schiffrin (Eds.). Oxford: Blackwell Publishers Ltd.

Mikhchi, H. H. (20I I). Standards of textuality: Rendering English and Persian texts based on a textual model. Journal of Universal Language, I2(I), 47-74. doi: https://doi.org/I0.22425/jul.20I I.I2.I.47

Nugroho, A. D. (2009). The generic structure of print advertisement of elizabeth arden's intervene: A multimodal discourse analysis. $k @ t a, \quad I I(\mathrm{I}), \quad 70-84 . \quad$ doi: https://doi.org/I0.9744/kata.I I.I.70-84

Pérez-Marín, M. (2016). Critical discourse analysis of colombian identities and humanature in national geographic magazine (I903-I952). Mexico: University of New Mexico.

Quirk, R., \& Greenbaum, S. (1990). A student's grammar of the English language. Harlow: Longman Group Ltd.

Quirk, R., Greenbaum, S., Leech, G., \& Svartvik, J. (1989). A comprehensive grammar of the English language (2nd ed.). Longman Group Ltd.

Rosmiyati, E. (2019). Error on Elliptical Constructions made by the first semester to the English Study Program PGRI University of Palembang. ELTE Journal (English Language Teaching and Education), 6(2), I35-I47. doi: http://dx.doi.org/I0.3185I/ elte.v6i2.2325

Swan, M. (2005). Practical english usage. Oxford: Oxford University Press.

Tárnyiková, J. (1992). Chapters from modern English syntax II (A communicative approach). Olomouc: University of Palackého Press.

Widdowson, H. (2007). Discourse analysis. Oxford: Oxford University Press. 
Yuen, C. Y. (2004). The construal of ideational meaning in print advertisements. Multimodal discourse analysis: Systemic functional perspectives, 2(I), I63-252.

Yule, G. (2016). The study of language. Cambridge: Cambridge. 